\title{
PERAN BANK WAKAF MIKRO DALAM PENGUATAN MODAL DAN PEMBERDAYAAN USAHA MIKRO DI SURABAYA
}

\author{
Muhammad Faiq Ramadhan \\ Departemen Ekonomi Syariah-Fakultas Ekonomi dan Bisnis-Universitas Airlangga \\ Email: M.Faiq.Ramadhan-2014@feb.unair.ac.id \\ Raditya Sukmana \\ Departemen Ekonomi Syariah-Fakultas Ekonomi dan Bisnis- Universitas Airlangga \\ Email: Raditya-s@feb.unair@ac.id
}

\begin{abstract}
:
This study aims to determine whether there are differences in the benefits obtained by micro-entrepreneurs between before obtaining financing capital from a Bank Wakaf Mikro and after obtaining financing capital from a Micro Waqf Bank. The approach used is a quantitative approach using analytical techniques t-paired test and using SPSS 20. The data used is primary data from questionnaires distributed to customers of Bank Wakaf Mikro. The results of this study indicate that the provision of capital carried out by Bank Wakaf Mikro has been effective in increasing the profits of the business of Bank Wakaf Mikro customers so that the welfare of the customers also increases thanks to the financial assistance provided. In addition, the role of guidance provided by the Bank Wakaf Mikro also plays a role in improving customer performance in carrying out its business.
\end{abstract}

Keywords: Bank Wakaf Mikro, Business Capital, Micro Business, Empowerment, Profit.

\section{PENDAHULUAN}

Krisis ekonomi yang dialami bangsa Indonesia secara tidak langsug telah meningkatkan jumlah penduduk miskin. Jumlah mereka dari waktu ke waktu semakin bertambah seiringan dengan terpuruknya kondisi ekonomi nasional yang masih terjadi saat ini. Salah satu upaya untuk meningkatkan kesejahteraan ekonomi masyarakat adalah dengan memaksimalkan potensi kelembagaan yang telah diatur oleh ajaran Islam, seperti zakat, infak, shadaqah, dan wakaf. Selain potensi kelembagaan tersebut di sisi lain ada peran penting dari sector UMKM yang tidak bisa dipandang sebelah mata.

Sektor Usaha Mikro, Kecil dan Menengah (UMKM) memiliki peran yang sangat penting dalam peningkatan pendapatan domestic bruto (PDB) dan penyerapan tenaga kerja di Negara maju ataupun di Negara-Negara berkembang. Selain itu keberadaan Usaha Mikro Kecil dan Menengah (UMKM) juga sangat dibutuhkan masyarakat khususnya masyarakat dengan kemampuan ekonomi yang rendah dan memiliki keterampilan yang terbatas (Wiliasih, 2013).

Perkembangan Usaha Mikro, Kecil dan Menengah (UMKM) menjadi faktor utama yang mendukung peningkatan berbagai macam kegiatan usaha keberadaan UMKM di Negara berekembang salah satunya di Indonesia. UMKM tidak bisa dipandang sebelah

\footnotetext{
${ }^{1}$ Jurnal ini merupakan bagian dari skripsi yang ditulis oleh Muhammad Faiq Ramadhan, NIM: 041411431113 , yang diuji pada 23 Juli 2019.
} 
Ramadhan, et al/Jurnal Ekonomi Syariah Teori dan Terapan Vol. 6 No. 11 November 2019: 2172-2184; PERAN BANK WAKAF MIKRO DALAM PENGUATAN MODAL DAN PEMBERDAYAAN USAHA MIKRO DI SURABAYA

mata karena dari masa krisis ekonomi hingga kini keberadaan UMKM mampu menjadi salah satu factor penggerak utama ekonomi di Indonesia. Terutama ketika krisis kegiatan Investasi dan pengeluaran pemerintah sanagat terbatas maka dari itu peran UMKM dalam pengembangan ekonomi rakyat sangat besar, (Prasetyo, 2008). Selain itu dari sisi kontribusinya terhadap peningkatan PDRB hanya $56,7 \%$ kontribusi yang diberikan dari sector ekspor dan $15 \%$ dari sector non migas. Namun UMKM masih tetap menyumbangkan 99\% dalam jumlah pelaku usaha di Indonesia, serta mempunyai andil $99,6 \%$ dalam penyerapan tenaga kerja, (BPS, 2001).

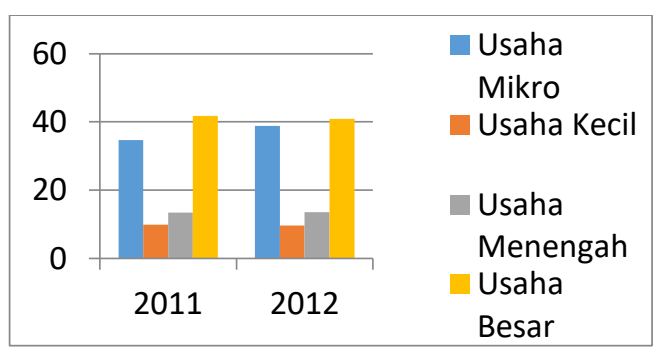

Dari grafik diatas dapat dilihat, bahwa pada tahun 2011 hingga 2012 terjadi pertumbuhan pada jumlah UMKM dan terjadi penurunan pada jumlah usaha besar. Contohnya pada 2011 jumlah UMKM berjumlah $34.64 \%$ kemudian meningkat menjadi $38.81 \%$ pada tahun 2012 dari jumlah kelompok usaha yang ada, sedangkan pada usaha besar terjadi penurunan dari tahun 2011 yang berjumlah $41.95 \%$ menjadi $40.92 \%$ pada tahun 2012 dari jumlah kelompok usaha yang ada.

UMKM memiliki kontribusi yang lebih besar dibandingkan Usaha besar dikarenakan UMKM lebih bisa bertahan ditengah krisis ekonomi yang menerpa suatu Negara, mereka juga memiliki konsumen tetap yang bersedia membeli produk mereka dan lebih mudah untuk menyerap tenaga kerja. Sedangkan usaha besar rentan terhadap perubahan iklim ekonomi di suatu Negara sehingga saat terjadi krisis perusahaan besar terpaksa harus melakukan PHK terhadap karyawannya.

Tapi pada kenyataannya para pelaku UMKM masih terhalang untuk berkembang dikarenakan oleh keterbatasan modal yang mereka miliki dikarenakan sulitnya akses untuk mendapatkan pinjaman modal dari lembaga lembaga keuangan,serta kurangnya perhatian pemerintah terhadap pelaku UMKM. Menurut (Mohamed Asmy Bin Mohd Thas Thaker Mustafa Omar Mohammed Jarita Duasa Moha Asri Abdullah , 2016) Ada beberapa factor yang menyebabkan para pelaku UMKM sulit untuk mendapatkan pinjaman modal antara lain, adalah : 1) Tidak adanya jaminan yang memadai untuk melakukan pinjaman modal pada institusi keuangan terkait; 2) Prosedur peminjaman yang rumit; 3) Besarnya bunga bank yang harus dibayar ketika melakukan pinjaman; 4) Profil usaha yang tidak sesuai dengan keinginan bank; 5) Kurangnya inovasiinovasi teknologi yang diadopsi oleh pelaku usaha mikro; 6) Kualitas barang yang dihasilkan relative rendah.

Maka dari itu pentingnya peran 
Ramadhan, et al/Jurnal Ekonomi Syariah Teori dan Terapan Vol. 6 No. 11 November 2019: 2172-2184;

PERAN BANK WAKAF MIKRO DALAM PENGUATAN MODAL DAN PEMBERDAYAAN USAHA MIKRO DI SURABAYA

pemerintah, masyarakat dan juga lembaga-lembaga keuangan dalam memberdayakan pelaku UMKM sangat diperlukan untuk mengembangkan usaha yang dijalankan oleh pelaku UMKM. Peran pemerintah diperlukan dalam pembuatan kebijakan kebijakan yang dapat mempengaruhi perkembangan UMKM di tiap Negara khususnya di Indonesia, sedangkan peran lembaga keuangan adalah untuk memberikan bantuan pinjaman dan penguatan modal bagi para pelakU UMKM.

Diperlukan juga peran aktif seluruh elemen masyarakat, salah satunya melalui pemberdayaan ekonomi umat yang juga menjalankan fungsi pendampingan. Salah satu elemen masyarakat yang memiliki fungsi strategis dalam pendampingan untuk mendorong perekonomian adalah pesantren.

Dengan potensi 28.194 pesantren ( data kementrian agama RI / pesantren mempunyai potensi yang amat besar untuk melakukan pemberdayaan umat dan memiliki peran dalam memangkas kesenjangan ekonomi dan menghapuskan kemiskinan khususnya masyarakat di sekitar pesantren.

Lembaga kevangan mikro sendiri merupakan cara terbaik untuk melakukan pendekatan dalam upaya pengembangan dan pemberdayaan usaha mikro dengan tujuan untuk menanggulangi kemiskinan dan pemerataan pendapatan. Beberapa masalah pendapatan yang dialami oleh
UMKM bisa diatasi oleh lembaga keuangan mikro.

Pada bulan Oktober tahun 2017, Pemerintah bekerja sama dengan OJK dan beberapa pesantren di jawa timur untuk membangun suatu lembaga pembiayaan yang ditujukan untuk membantu pengusaha mikro disekitar pesantren yang bernama Bank Wakaf Mikro ( BWM ). Hal yang melatar belakangi pembentukan BWM berawal dari komitmen pemerintah RI untuk membantu permodalan usaha mikro, serta keprihatinan terhadap para peaku usaha mikro yang susah untuk mengakses modal di bank karena tidak adanya jaminan, bank menganggap usaha kecil memiliki resiko besar untuk bangkrut, dan beban bunga yang harus ditanggung oleh peminjam. Selain itu karena terdapat banyaknya pesantren di daerah jawa timur pemerintah tertarik untuk menjadikan pesantren sebagai lembaga pengelola dana wakaf tunai yang nanti disalurkan kepada para pelaku usaha mikro.

BWM merupakan lemabaga yang memberikan pinjaman kepada pelaku usaha mikro dimana yang menerima pinjaman tersebut dibebaskan dari biaya administrasi dan biaya lain lain, BWM menaungi masyarakat - masyarakat kecil dan akan menjadi solusi akses pembiayaan yang mudah yang diperuntukkan untuk masyarakat kecil dan bebas dari rentenir BWM juga berfungsi sebagai wadah untuk memepersiapkan 
Ramadhan, et al/Jurnal Ekonomi Syariah Teori dan Terapan Vol. 6 No. 11 November 2019: 2172-2184;

PERAN BANK WAKAF MIKRO DALAM PENGUATAN MODAL DAN PEMBERDAYAAN USAHA MIKRO DI SURABAYA

para peminjam untuk mengakses lembaga keuangan formal. Dalam melaksanakan tugasnya BWM tidak bekerja sendirian ada lembaga lain yang membantu BMW dalam pelaksanaan tugasnya yaitu adalah Lembaga Amil Zakat Nasional atau LAZNAS.

BWM merupakan lembaga yang memberikan pinjaman kepada pelaku usaha mikro dimana yang menerima pinjaman tersebut dibebaskan dari biaya administrasi dan biaya lain lain, BWM menaungi masyarakat - masyarakat kecil dan akan menjadi solusi akses pembiayaan yang mudah yang diperuntukkan untuk masyarakat kecil dan bebas dari rentenir BWM juga berfungsi sebagai wadah untuk memepersiapkan para peminjam untuk mengakses lembaga keuangan formal. Dalam melaksanakan tugasnya BWM tidak bekerja sendirian ada lembaga lain yang membantu BMW dalam pelaksanaan tugasnya yaitu adalah Lembaga Amil Zakat Nasional atau LAZNAS.

Dalam pelaksanaannya LAZNAS menyediakan dana sebesar Rp.3.630.000.000,-kepada BWM untuk nantinya disalurkan kepada 3.876 nasabah diseluruh Indonesia (https://indopos.co.id/read/2018/04/05/13 3682/nasabah-melonjak-ojk-segera-

tambah-izin-usaha-bwm). Besar pinjaman yang diberikan kepada peminjam adalah berkisar Rp.1.000.000.- hingga Rp.3.000.000,- dana wakaf yang diberikan merupakan wakaf muqayyad yaitu dana wakaf yang diberikan dapat digunakan untuk urusan tertentu yang dapat bermanfaat bagi orang lain.

Dalam pelaksanaannya BWM menerapkan akad mudharabah dimana nantinya setelah pemberian pinjaman BWM akan meminta nisbah bagi hasil kepada peminjam sebesar $3 \%$ dari keuntungan yang mereka dapatkan selama satu bulan, tetapi pada saat ini BWM juga menawarkan pinjaman dengan akad qardh atau pinjaman kebaikan dimana para nasabah dapat meminjam tanpa harus membagi keuntungan yang mereka dapat kepada BWM, tetapi mereka diwajibkan membayar angsuran yang jumlahnya sudah ditentukan diawal oleh BWM sesuai dengan jumlah pinjaman yang mereka dapat.

Pada tahun 2018 BWM di Surabaya telah menyalurkan pinjaman kepada kurang lebih 200 orang nasabah disekitar pondok pesantren Assalafi Al fithrah Surabaya pihak pengelola BWM mengatakan kuota peminjam ini dapat bertamabah seiring berjalannya waktu.

BWM merupakan salah satu contoh langkah nyata pemerintah dalam pemberdayaan dan pengembangan usaha mikro, karena didalamnya terdapat hubungan baik antar tiga golongan yang berperan penting yaitu pemerintah, lembaga kevangan dan peminjam. lembaga keuangan yang diwakili oleh LAZNAS, dan BWM sedangkan pemerintah diwakili oleh Otoritas Jasa Kevangan ( OJK). Dan Kementrian Koperasi 
Ramadhan, et al/Jurnal Ekonomi Syariah Teori dan Terapan Vol. 6 No. 11 November 2019: 2172-2184;

PERAN BANK WAKAF MIKRO DALAM PENGUATAN MODAL DAN PEMBERDAYAAN USAHA MIKRO DI SURABAYA

Diharapkan dengan terbentuknya BWM, pemberdayaan usaha mikro dapat berjalan secara efektif dan berkesinambungan kedepannya sehingga tujuan yang ingin dicapai dapat terealisasikan segera.

\section{LANDASAN TEORI}

Menurut Undang-Undang No.20 Tahun 2008 tentang usaha Mikro Kecil dan Menengah, dijelaskan bahwa:

1. Usaha Mikro adalah usaha produktif milik orang perorangan dan/atau badan usaha perorangan yang memenuhi kriteria Usaha Mikro sebagai berikut:

a) Memiliki kekayaan bersih paling banyak Rp50.000.000,00 (lima puluh juta rupiah) tidak termasuk tanah dan bangunan tempat usaha; atau

b) Memiliki hasil penjualan tahunan paling banyak Rp300.000.000,00 (tiga ratus juta rupiah).

2. Usaha Kecil adalah usaha ekonomi produktif yang berdiri sendiri, yang dilakukan oleh orang perorangan atau badan usaha yang bukan merupakan anak perusahaan atau bukan cabang perusahaan yang dimiliki, dikuasai, atau menjadi bagian baik langsung maupun tidak langsung dari Usaha Menengah atau Usaha Besar yang memenuhi kriteria Usaha Kecil sebagai berikut:

a) Memiliki kekayaan bersih lebih dari Rp50.000.000,00 (lima puluh juta rupiah) sampai dengan paling banyak Rp500.000.000,00 (lima ratus juta rupiah) tidak termasuk tanah dan bangunan tempat usaha; atau

b) memiliki hasil penjualan tahunan lebih dari Rp300.000.000,00 (tiga ratus juta rupiah) sampai dengan paling banyak Rp2.500.000.000,00 (dua milyar lima ratus juta rupiah).

3. Usaha Menengah adalah usaha ekonomi produktif yang berdiri sendiri, yang dilakukan oleh orang perorangan atau badan usaha yang bukan merupakan anak perusahaan atau cabang perusahaan yang dimiliki, dikuasai, atau menjadi bagian baik langsung maupun tidak langsung dengan Usaha Kecil atau Usaha Besar dengan jumlah kekayaan bersih atau hasil penjualan tahunan dengan criteria sebagai berikut:

a) memiliki kekayaan bersih lebih dari Rp500.000.000,00 (lima ratus juta rupiah) sampai dengan paling banyak Rp10.000.000.000,00 (sepuluh milyar rupiah) tidak termasuk tanah dan bangunan tempat usaha; atau

b) memiliki hasil penjualan tahunan lebih dari Rp2.500.000.000,00 (dua milyar lima ratus juta rupiah) sampai dengan paling banyak Rp50.000.000.000,00 (lima puluh milyar rupiah).

Sedangkan menurut Badan Pusat Statistik (BPS) UKM dikualisifikasikan berdasarkan kuantitas atau jumlah tenaga kerja. Usaha kecil merupakan 
Ramadhan, et al/Jurnal Ekonomi Syariah Teori dan Terapan Vol. 6 No. 11 November 2019: 2172-2184;

PERAN BANK WAKAF MIKRO DALAM PENGUATAN MODAL DAN PEMBERDAYAAN USAHA MIKRO DI SURABAYA

badan usaha yang mempunyai jumlah tenaga kerja berjumlah 5 sampai 19 orang sedangkan usaha menengah merupakan usaha yang memiliki tenaga kerja berjumlah 20 sampai 99 orang.

Prasetyo (2008) menyatakan bahwa Peran UMKM juga telah telah terwujud dari masa krisis sampai saat ini. Selama masa krisis ekonomi hingga kini, keberadaan UMKM mampu menjadi faktor penggerak utama ekonomi di Indonesia. Terutama ketika krisis kegiatan investasi dan pengeluaran pemerintah sangat terbatas, maka pada saat itu peran UMKM sebagai bentuk ekonomi rakyat sangat besar.

Pentingnya peran UMKM terutama di Negara-negara berkembang sering dihubung-hubungkan dengan masalah ekonomi dan social di dalam negeri seperti masalah pengangguran, kemiskinan, ketimpangan pendapatanan, juga masalah urbanisasi dan juga dampak negatifnya. Maka dari itu disimpulkan bahwa kehadiran UMKM sendiri diaharapkan dapat member suatu kontribusi yang dapat meningkatkan upaya penanggulangan masalah masalah tersebut.

Keunggulan yang dimiliki oleh UMKM itu sendiri menjadi salah satu bagian penting dalam Negara dengan tujuan mencapai peningkatan dalam kesejahteraan dan pembangunan ekonomi Negara. hal ini dapat dibuktikan dari daya tahan UMKM yang dapat terus bertahan dalam krisis ekonomi dan juga kontribusinya dalam penyerapan tenaga kerja dan peningkatan Pendapatan Domestik Bruto (PDB) suatu Negara hal ini menyebabkan UMKM dapat diharapkan menjadi tulang punggung perekonomian Negara kedepannya .

Menurut United Nationals Development Programs pemberdayaan masyarakat adalah sebuah proses yang memungkinkan tiap individu atau kelompok untuk merubah keseimbangan dan kekuasaan dalam ranah social, ekonomi maupun politik pada masyarakat maupun komunitas.

Konsep

pemberdayaan

masyarakat adalah:

1. Memotivasi seseorang menjadi lebih berpartisispasi dalam membuat dan mengambil keputusan dalam pekerjaannya

2. Menempatkan orang bertanggung jawab atas apa yang mereka kerjakan

3. Memiliki wewenang dan memiliki inisiatif untuk melakukan sesuatu yang dianggap perlu

4. Mendorong terjadinya inisiatif dan respon, sehingga semua permasalahan yang dihadapi dapat dipecahkan secepatnya dan sefleksibel mungkin.

Wakaf sendiri berasal dari bahasa arab "waqafa" yang berarti menahan atau berhenti atau diam di tempat. Secara syariah, wakaf berarti menahan harta yang ada kemudian memberikan manfaatnya di jalan Allah.

Perintah untuk melakukan wakaf dan sumber hokum yang menjelaskan 
Ramadhan, et al/Jurnal Ekonomi Syariah Teori dan Terapan Vol. 6 No. 11 November 2019: 2172-2184;

PERAN BANK WAKAF MIKRO DALAM PENGUATAN MODAL DAN PEMBERDAYAAN USAHA MIKRO DI SURABAYA

tentang wakaf terdapat pada Surat Al-

Imran ayat 92 sebagaimana berikut:



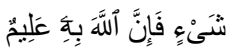

"Kamu sekali-kali tidak sampai kepada kebajikan (yang sempurna), sebelum kamu menafkahkan sehahagian harta yang kamu cintai. Dan apa saja yang kamu nafkahkan maka sesungguhnya Allah mengetahuinya".

Pada ayat diatas dijelaskan sebaiknya kita tidak mencintai harta dunia secara berlebihan akan lebih baik jika harta tersebut kita manfaatkan di jalan yang diridhoi oleh Allah agar kita juga dapat mendapatkan manfaat di dunia dan di akhirat dari harta tersebut.

Bank Wakaf Mikro adalah Lembaga Kevangan Mikro Syariah yang didirikan atas izin Otoritas Jasa Keuangan (OJK) dan bertujuan menyediakan akses permodalan atau pembiayaan bagi masyarakat kecil yang belum memiliki akses pada lembaga keuangan formal. Lembaga ini diharapkan dapat meningkatkan taraf hidup masyarakat, serta mampu mengurangi ketimpangan dan kemiskinan.

Konsep dasar Bank Wakaf Mikro pada dasarnya sama dengan Lembaga kevangan mikro yang berbasis syariah pada umumnya yaitu sebagai berikut:

1. Berbadan hokum koperasi jasa dengan izin usaha Lembaga Keuangan Mikro Syariah

2. Menyediakan pembiayaan dengan prinsip syariah antara lain dengan produk pembiayaan berupa mudharabah, murabahah, dan qardh

3. Tidak menghimpun dana (non-deposit taking)

4. Imbal hasil rendah setara $3 \%$ dalam satu tahun

5. Tanpa agunan

6. Diberi pengarahan, pelatihan dan pendampingan

7. Diawasi OJK berkoordinasi dengan kementrian koperasi, pesantren dan masyarakat.

Pada dasarnya Bank Wakaf Mikro mempunyai fungsi intermediasi dimana fungsi Intermediasi bertindak sebagai perantara atau lembaga yg menghubungkan antara masyarakat yang kelebihan dana (surplus) kepada masyarakat yang membutuhkan dana (deficit).

Dalam hal intermediasi Bank Wakaf Mikro memiliki produk dan jasa kevangan, yaitu penghimpunan (sumber dana) dan pembiayaan. Produk dan jasa penghimpunan (sumber dana) Bank Wakaf Mikro menggunanakan sistem wakaf muqayyad yaitu pembiayaan wakaf dimana wakif mensyaratkan agar harta yang diwakafkan itu hanya boleh dikelola dengan cara tertentu dan diberikan kepada pihak tertentu.

Selain fungsi pembiayaan dan Intermediasi dan pembiayaan Bank Wakaf Mikro memiliki manfaat lain yaitu sebagai berikut:

1. Pelatihan dan Pendampingan

2. Pembiayaan Modal Usaha 
Ramadhan, et al/Jurnal Ekonomi Syariah Teori dan Terapan Vol. 6 No. 11 November 2019: 2172-2184;

PERAN BANK WAKAF MIKRO DALAM PENGUATAN MODAL DAN PEMBERDAYAAN USAHA MIKRO DI SURABAYA

3. Meningkatkan literasi dan inklusi kevangan

4. Menghindarkan nasabah dari rentenir

5. Mengurangi ketimpangan dan kemiskinan

6. Menerapkan sistem jemput bola.

Perkembangan usaha dalam konteks ilmu pendidikan adalah merupakan suatu perubahan kearah yang lebih maju atau lebih dewasa (Suwarsono, 1996:173). Tolak ukur perkembangan usaha atau keberhasilan usaha haruslah merupakan parameter yang dapat diukur sehingga tidak bersifat nisbi atau bahkan bersifat maya yang sulit dapat dipertanggungjawabkan. Semakin konkrit tolak ukur itu semakin mudah bagi semua pihak untuk memahami serta membenarkan atas diraihnya keberhasilan tersebut (Suryati, 2012:43).

Menurut Indriyo Gitosudarmo dalam skripsi Suryati (2012:44) menyatakan ukuran terhadap keberhasilan dari kebijakan bisnis tersebut dapat berupa besar kecilnya penghasilan (Income) atau keuntungan (Profity) yang diperoleh. Berdasarkan pernyataan tersebut dapat dikatakan bahwa dengan naiknya keuntungan yang diterima maka usaha mikro juga dapat dikatakan berkembang.

\section{METODE PENELITIAN}

Pendekatan yang dilakukan dalam penelitian ini menggunakan metode kuantitatif, metode kuantitatif digunakan untuk meneliti sampel dari populasi tertentu kemudian mengolah data yang berupa kuesioner penelitian yang telah didapat dari nasabah kemudian diolah dengan uji statistic sehingga dapat menjawab rumusan masalah yang ada.

Definisi operasional untuk masingmasing variabel yang digunakan dalam penelitian ini menjelaskan cara tertentu yang digunakan oleh peneliti dalam mengukur variabel-variabel yang akan digunakan dalam penelitian. Adapun variabel-variabel yang digunakan dalam penelitian ini adalah:

a. Variabel (X1): Keuntungan nasabah sebelum mendapatkan pembiayaan dari Bank Wakaf Mikro

b. Variabel (X2): Keuntungan nasabah sesudah mendapatkan pembiayaan dari Bank Wakaf Mikro.

Teknik pengambilan sampel yang digunakan dalam penelitian ini menggunakan teknik sampel yang dijelaskan oleh Arikunto (2006:112), yang mengatakan bahwa "apabila subjeknya kurang dari seratus, lebih baik diambil semuanya sehingga penelitian yang dilakukan merupakan penelitian populasi. Tetapi jika jumlah subjeknya besar, dapat diambil antara 10-15\% atau 15-25\%."

Dari pendapat diatas maka peneliti mengambil jumlah sampel sebesar $25 \%$ dari total populasi yang berjumlah 203 orang dan mendapatkan jumlah sampel sebesar 50,75 dibulatkan menjadi 51 sampel.

Pada penelitian ini, sesuudah dilakukan pengumpulan data, maka data tersebut dapat dianalisis menggunakan uji t-berpasangan menggunakan aplikasi 
Ramadhan, et al/Jurnal Ekonomi Syariah Teori dan Terapan Vol. 6 No. 11 November 2019: 2172-2184; PERAN BANK WAKAF MIKRO DALAM PENGUATAN MODAL DAN PEMBERDAYAAN USAHA MIKRO DI SURABAYA

SPSS 20 untuk kemudian diperoleh kesimpulan.

Sebelum diolah menggunakan SPSS 20 data terlebih dahulu di uji Normalitas, uji normalitas digunakan untuk menguji apakah data sudah terdistribusi normal atau belum. Kemudian data diolah dengan uji t-berpasangan untuk menentukan perbedaan atau perbandingan variabel yang diteliti.

\section{HASIL DAN PEMBAHASAN}

\section{Uji Normalitas}

\begin{tabular}{|ll|l|}
\hline & & $\begin{array}{l}\text { Unstandardized } \\
\text { Residual }\end{array}$ \\
\hline $\mathrm{N}$ & Mean & 51 \\
Normal Parameters ${ }^{\mathrm{a}, \mathrm{b}}$ & Std. Deviation & 26223.23439256 \\
& Absolute & .160 \\
& Positive & .160 \\
Most Extreme Differences & Negative & -130 \\
& & 1.141 \\
Kolmogorov-Smimov Z & & .148 \\
Asymp. Sig. (2-tailed) & &
\end{tabular}

Sumber: Data Diolah

Berdasarkan tabel diatas, pada

hasil uji Kolmogorov-Smirnov diperoleh hasil Asymp. Sig (2-tailed) sebesar 0.148, sedangkan dasar pengambilan keputusan dalam uji normalitas Kolmogorov-Smirnov menyebutkan bahwa jika nilai signifikansi lebih besar dari 0,05 maka data penelitian sudah terdistribusi secara normal.

\section{Uji t-Berpasangan}

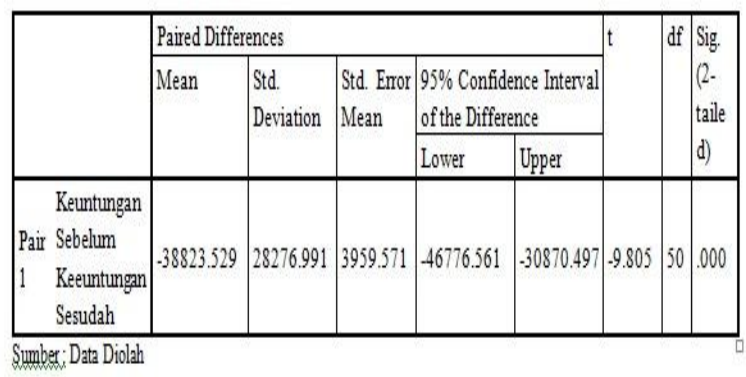

Berdasarkan tabel diatas, pada hasil uji- $†$ berpasangan diperoleh hasil probabilitas
Sig (2-tailed) sebesar 0.000, sedangkan dasar pengambilan keputusan dalam uji ini menjelaskan bahwa jika nilai probabilitas atau Sig (2-tailed) $<0,05$ maka terdapat perbedaan yang signifikan antar dua data yang dibandingkan.

Berdasarkan output SPSS diatas, diketahui bahwa nilai Sig (2-tailed) yang didapat sebesar 0,000 0,05 maka dapat disimpulkan bahwa terdapat perbedaan signifikan antara keuntungan yang didapat sebelum mendapatkan pembiayaan dari BWM dan setelah mendapatkan pembiayaan dari BWM.

\section{Pembahasan}

Berdasarkan pengujian hipotesis menggunakan metode uji-† berpasangan yang didasarkan pada nilai signifikansi yang diperoleh yaitu sebesar 0.000 yang dimana nilai itu $<0,05$, hal ini berarti ada perbedaan yang signifikan pada variabel keuntungan usaha antara sebelum dan sesudah mendapatkan pembiayaan dari Bank Wakaf Mikro. Sedangkan nilai thitung yang didapatkan bernilai negatif yaitu sebesar -9.805 menunjukkan keuntungan yang diperoleh sebelum pembiayaan lebih rendah dibandingkan dengan keuntungan yang diperoleh setelah pembiayaan. Hal ini menunjukkan bahwa setelah mendapatkan pinjaman dana dari Bank Wakaf Mikro para pelaku usaha mikro mendapatkan tambahan keuntungan dari usaha yang mereka jalankan dari yang sebelumnya keuntungan yang mereka dapatkan 
Ramadhan, et al/Jurnal Ekonomi Syariah Teori dan Terapan Vol. 6 No. 11 November 2019: 2172-2184;

PERAN BANK WAKAF MIKRO DALAM PENGUATAN MODAL DAN PEMBERDAYAAN USAHA MIKRO DI SURABAYA

berjumlah dibwaha keuntungan yang mereka dapatkan setelah mendapatkan pinjaman.

Pembiayaan yang didapatkan oleh nasabah, menurut pernyataan responden kebanyakan digunakan untuk peningkatan volume usaha dan digunakan untuk menambah peralatanperalatan yang akan menunjang usaha mereka. Pinjaman ini tidak boleh digunakan untuk kepentingan pribadi nasabah misalkan membayar utang, membayar biaya sekolah, digunakan untuk konsumsi sehari-hari, pinjaman ini hanya boleh digunakan untuk membiayai hal yang berkaitan tentang usaha yang dijalankan oleh nasabah.

Penelitian ini berhasil membuktikan Bank Wakaf Mikro Wava Mandiri Al Fithrah di Surabaya dapat memberdayakan para pelaku usaha mikro binaannya hal ini dapat dilihat dari indikator perkembangan usaha yaitu dengan meningkatnya keuntungan yang otomatis dengan adanya peningkatan keuntungan nasabah ini turut meningkatkan kesejahteraan para pelaku usaha mikro, peningkatan keuntungan ini juga dipengaruhi dari pihak Bank Wakaf Mikro yang rutin melakukan pembinaan tiap minggu untuk mengawasi usaha yang dijalankan oleh nasabah juga memberikan solusi atas masalah yang dialami oleh pelaku usaha mikro dan masukan-masukan yang tepat kepada nasabah agar usaha yang dijalankan bisa berkembang.

Selain memberikan pinjaman
modal kepada nasabah dalam
penelitian ini juga membuktikan pembinaan yang diberikan oleh Bank Wakaf Mikro kepada nasabahnya turut membantu peningkatan produktivitas para pelaku usaha mikro sehingga bisa mendorong peningkatan Laba yang didapat oleh pelaku usaha mikro, pembinaan-pembinaan yang diberikan berupa:

a. Pembinaan agama, hal ini dilakukan dengan cara menghadirkan ustadz untuk memberikan kajian-kajian untuk memperdalam ilmu agama para nasabah Bank Wakaf Mikro. Dengan adanya pembinaan dalam bidang agama para nasabah merasa sangat antusias dikarenakan mereka senang bisa mendapatkan ilmu baru seperti ilmu spiritual dan lainnya.

b. Pembinaan manajerial, hal ini dilakukan dengan menghadirkan pengusaha-pengusaha yang telah sukses untuk memberikan pembinaan tentang bagaimana cara menjalankan bisnis dengan baik dan benar, bagaimana mengatur keuangan mereka. Para nasabah sangat terbantu dengan adanya pembinaan ini mereka dapat mengatur bisnis mereka dengan baik dan benar.

c. Pembinaan marketing dan pemasaran, hal ini dilakukan oleh Bank Wakaf Mikro dengan cara memberikan arahanarahan kepada nasabah bagaimana cara mempromosikan usaha mereka, 
Ramadhan, et al/Jurnal Ekonomi Syariah Teori dan Terapan Vol. 6 No. 11 November 2019: 2172-2184;

PERAN BANK WAKAF MIKRO DALAM PENGUATAN MODAL DAN PEMBERDAYAAN USAHA MIKRO DI SURABAYA

contohnya dengan mengikuti pameran maupun bazaar. Cara ini dirasa sangat efektif menrut nasabah selain terbantu dalam mempromosikan bisnis mereka, mereka juga mendapat pengalaman baru yang belum pernah mereka dapatkan sebelumnya dalam menjalankan bisnis, mereka juga belajar cara memasarkan produk merek dengan baik dan benar.

d. Pendampingan, dilakukan dengan cara melihat dan mengevaluasi perkembangan usaha para nasabah setiap satu minggu sekali sehingga nasabah Bank Wakaf Mikro tidak kebingungan jika mendapatkan masalah dalam menjalankan bisnisnya, dengan adanya pendampingan yang diberikan oleh pihak Bank Wakaf Mikro tiap satu minggu sekali nasabah merasa sangat terbantu dikarenakan mereka dapat bertanya dan mencari solusi disaat mendapatkan kesulitan ketika menjalankan bisnisnya.

\section{Simpulan}

Berdasarkan pembahasan yang telah dilakukan pada bab sebelumnya, penelitian ini bertujuan untuk mengetahui peran bank wakaf mikro pada pemberdayaan nasabah binaan Bank Wakaf Mikro Wava Mandiri Al Fithrah Surabaya. Berdasarkan hasil pengujian dan analisis data yang dilakukan pada nasabah Bank Wakaf Mikro Wava Mandiri Al Fithrah Surabaya melalui penyebaran kuesioner dengan sampel yang memenuhi kriteria penelitian berjumlah 54 sampel, maka dapat diambil kesimpulan sebagai berikut:

a. Terdapat perbedaan keuntungan yang didapatkan nasabah sebelum mendapatkan pembiayaan dari Bank Wakaf Mikro dan sesudah mendapatkan pembiayaan Bank Wakaf Mikro. Hal ini menunjukkan bukti bahwa setelah mendapatkan tambahan modal dari Bank Wakaf Mikro keuntungan usaha dari nasabah meningkat, hal ini dikarenakan modal yang diterima oleh nasabah, mereka gunakan untuk meningkatkan volume usaha dan membeli peralatanperalatan tambahan untuk menunjang kegiatan jual beli mereka sehingga mereka bisa lebih produktif dalam menjalankan usaha.

b. Pembinaan yang dilakukan oleh pihak Bank Wakaf Mikro juga turut mempengaruhi dalam perkembangan usaha para nasabah, pihak dari Bank Wakaf Mikro dengan setia selalu mendampingi para nasabah dalam menjalankan bisnisnya, tidak hanya itu mereka juga memberikan solusi dan masukan-masukan yang terbaik atas masalah-masalah yang dihadapi oleh nasabah dalam menjalankan usahanya, sehingga para nasabah tidak kebingungan jika mendapatkan hambatan dalam menjalankan usahanya.

\section{DAFTAR PUSTAKA}

Barat, D. I. S. (2003). Studi peningkatan peran bank perkreditan rakyat 
Ramadhan, et al/Jurnal Ekonomi Syariah Teori dan Terapan Vol. 6 No. 11 November 2019: 2172-2184;

PERAN BANK WAKAF MIKRO DALAM PENGUATAN MODAL DAN PEMBERDAYAAN USAHA MIKRO DI SURABAYA

(bpr) dalam pembiayaan usaha mikro kecil (umk) di sumatera barat $*, 1-37$.

Dan, I., Keberadaan, P., Pencilan, D. Kasus, S., Kunjungan, J., \& Asing, P. (2009). Identifikasi dan pengaruh keberadaan data pencilan (outlier), 56-62.

Gibb, A., \& Li, J. (2003). Organizing for enterprise in China: what can we learn from the Chinese micro, small, and medium enterprise development experience, 35, 403421. https://doi.org/10.1016/S00163287(02)00089-7

Gina, W., \& Effendi, J. (2014). Program Pembiayaan Lembaga Keuangan Mikro Syariah ( LKMS ) dalam Peningkatan Kesejahteraan Pelaku Usaha Mikro ( Studi Kasus BMT Baitul Karim Bekasi ) Financing Program in Microfinance Institution ( LKMS ) of Welfare Enhancing for Micro Business Enterprises ( Study Case in BMT Baitul Karim Bekasi , 1 Pendahuluan, 3(1), 33-43.

Gunartin. (2017). Pendidikan, Eduka Jurnal Vol, Bisnis, 1 (V), 59-74.

Hendra, T. (n.d.). PEMBERDAYAAN MASYARAKAT DALAM PERSPEKTIF AL QUR'AN Oleh: Tomi Hendra, M.Sos, 30-50.

Https://www.ojk.go.id/id/berita-dankegiatan/infoterkini/Pages/Infografis-BankWakaf-Mikro-Mendorong-EkonomiUmat.aspx. (2018). Infografis Bank
Wakaf Mikro Mendiring Ekonomi Umat.

Https://www.ojk.go.id/id/kanal/perbankan /regulasi/undangundang/Pages/undang-undangnomor-21-tahun-2008-tentangperbankan-syariah.aspx. (2010). Regulasi Undang-Undang.

Mahmood, S. (2011). Microfinance and women entrepreneurs in Pakistan, 3(3), 265-274. https://doi.org/10.1108/175662611 1 1169340

Maryati, S. (2014). Peran Bank Pembiayaan Rakyat Syariah Dalam Pengembangan UMKM dan Agribisnis Pedesaan di Sumatera Barat. Ekonomi Dan Penidikan Ekonomi, 3(1), 17.

Pada, M., \& Muamalat, B. (n.d.). Penerapan prinsip syariah dalam akad pembiayaan murabahah pada bank muamalat.

Prasetyo, P. E. (2008). Peran Usaha Mikro Kecil dan Menengah (UMKM) dalam Kebijakan Penanggulangan Kemiskinan dan Pengangguran. Jurnal Akuntansi Dan Manajemen , 2(1), 1-13. Retrieved from http://ekonomi.upy.ac.id/files/PER AN USAHA MIKRO KECIL DAN MENENGAH (UMKM) DALAM KEBIJAKAN PENANGGULANGAN KEMISKINAN DAN PENGANGGURAN (P. EKO PRASETYO).pdf 
Ramadhan, et al/Jurnal Ekonomi Syariah Teori dan Terapan Vol. 6 No. 11 November 2019: 2172-2184; PERAN BANK WAKAF MIKRO DALAM PENGUATAN MODAL DAN PEMBERDAYAAN USAHA MIKRO DI SURABAYA

Prayogi, M. A., Siregar, L. H., Fakultas, D., \& Universitas, E. (2017). Pengaruh Pembiayaan Mikro Syariah Terhadap Tingkat Perkembangan Usaha Mikro Kecil Menengah I UMKM ) The Influence of Sharia Micro Financing On The Development Rate of Micro Small and Medium Enterprises ( UMKM ), $17(2), 121-131$.

Rianto, M. N., \& Arif, A. (2010). Pemberdayaan masyarakat berbasis wakaf uang, 44(li), 1-14.

Sa, M. (n.d.). MUDHARABAH DALAM FIQIH DAN PERBANKAN SYARI ' $A H, 302-$ 323.
Satrio, M. A., \& Manajemen, P. (2015). Qardhul hasan sebagai wujud pelaksanaan csr dan kegiatan filantropi lembaga keuangan syariah untuk pemberdayaan masyarakat, 23(2), 104-111.

Usman, A. (2015). Analysis the Impact of Microfinance on Poverty Reduction, 13, 104-117.

Wiliasih, L. A. P. E. A. (2013). Akses UMKM Terhadap Pembiayaan Mikro Syariah dan Dampaknya Terhadap Perkembangan Usaha: Kasus BMT Tadbiirul Ummah. Jurnal AlMuzara'ah, I(1), 56-67. https://doi.org/10.29244/JAM.1.1.\% $\mathrm{P}$ 